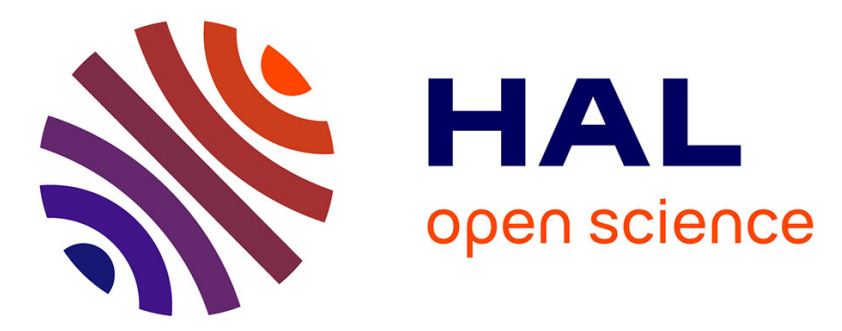

\title{
The Torchis of Northern France: Ethnoarchaeological Research on the Technological Variability and Decay Processes of Wattle and Daub Dwellings
}

Alessandro Peinetti

\section{- To cite this version:}

Alessandro Peinetti. The Torchis of Northern France: Ethnoarchaeological Research on the Technological Variability and Decay Processes of Wattle and Daub Dwellings. Stefano Biagetti; Francesca Lugli. The Intangible Elements of Culture in Ethnoarchaeological Research, Springer International Publishing, pp.275-282, 2016, 10.1007/978-3-319-23153-2_22 . halshs-01360081

\section{HAL Id: halshs-01360081 \\ https://shs.hal.science/halshs-01360081}

Submitted on 27 Sep 2018

HAL is a multi-disciplinary open access archive for the deposit and dissemination of scientific research documents, whether they are published or not. The documents may come from teaching and research institutions in France or abroad, or from public or private research centers.
L'archive ouverte pluridisciplinaire HAL, est destinée au dépôt et à la diffusion de documents scientifiques de niveau recherche, publiés ou non, émanant des établissements d'enseignement et de recherche français ou étrangers, des laboratoires publics ou privés. 


\title{
Accepted manuscript
}

Peinetti A. (2016) - The "torchis" of northern France: ethnoarchaeological research on the technological variability and decay processes of wattle and daub dwellings, in Biagetti S., Lugli F. (dir.), The Intangible Elements of Culture in the Ethnoarchaeological Research, Springer, pp. 275-282.

פ2springer

p. 275

\section{The Torchis of Northern France: Ethnoarchaeological Research on the Technological Variability and Decay Processes of Wattle and Daub Dwellings}

\author{
Alessandro Peinetti \\ UMR 5140, Archéologie des Sociétés Méditerranéennes (Université Montpellier 3 - CNRS-MCC), 390, avenue \\ de Pérols , 34970 Lattes , France ; \\ Labex ARCHIMEDE (Programme IA-ANR-11-LABX-0032-01, Route de Mende, 34199 Montpellier, France ; \\ Dipartimento di Storia Culture Civiltà , Università di Bologna , 2, Piazza San Giovanni in Monte, 40124 \\ Bologna , Italy. \\ e-mail: alessandro.peinetti@gmail.com
}

\section{Introduction}

Archaeologists often use the term "wattle and daub" in their reconstructions, sometimes without clear argumentation or direct evidence in the field. The French word "torchis" can be linked, more or less, to the wattle and daub technique. The torchis is characterized by the installation of daub on a frame. The earthen material doesn't have a load-bearing role, but a simple infi lling purpose for the wooden framework of the wall (Houben and Guillaud 1989 , pp. 186-187). In northern France, a mix of earth (silty clay), straw and water is traditionally used as daub. The nature of the frame normally influences daub installation practices, especially in terms of gestures (Lahure 1989, p. 7).

Observations on wattle and daub variability in modern contexts can help by leaving some prejudices on earthen construction techniques and increasing our knowledge of ancient skills, by recognizing various choices and gestures in material traces. Moreover, it is useful and necessary to record all the decay processes and human behaviors that contribute to the formation of the archaeological deposit, as well as to its erosion or removal (Schiffer 1995 , pp. 69-72; Épaud 2009, p. 123). This field enquiry has been carried out on modern wattle and daub buildings in 
northern France ${ }^{1}$, focusing on barns and rural dwellings built between the nineteenth and the first half of the twentieth centuries.

\section{Raw Materials and Technical Choices in Context}

In northern France, the wattle and daub constructions always stand on a base, usually made with bricks ${ }^{2}$, to protect earthen and wooden materials from soil moisture. A load-bearing timber framework ( pan de bois ) supports the roof (Fig. 22.1a ). In Picardie and Pas-de-Calais, a horizontal lathing is externally nailed to this framework ${ }^{3}$. Laths are variably spaced, from 4 to $10 \mathrm{~cm}$ on average (Fig. 22.1a ). In nearest regions, the frame that supports the torchis has very different morphologies and is extremely variable in terms of woodworking, assembling strategies, and spacing between frame elements (Fig. 22.1b-d ).

Generally, a first distinction can be made between visible frameworks (charpentes apparentes, when daub is applied on laths or wattle between the colombages and the load-bearing framework is visible from the exterior of the dwelling) and hidden frameworks ( charpentes cachées, when the framework is completely covered by $\mathrm{daub})^{4}$. The first solution is adopted preferably in regions where good-quality timber, which is more resistant to weathering, is available ${ }^{5}$.

Local silty clay is normally used. The daub of older buildings often includes coarse gravel and small cobbles that were not removed after the extraction of the sediment. Reusing earthen building materials from old dismantled dwellings, and

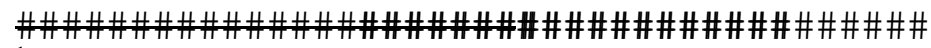

${ }^{1}$ The field activities were main focused on the Somme Department, with more general observations carried out in the nearest regions (Haute-Normandie, Oise, Pas-de-Calais), in order to realize: direct surveys and observations on dwellings (technological and morphological variability); interviews with inhabitants and craftsmen; participation in wattle and daub dwelling renovations; sampling. This research was funded by the University of Bologna (dir., M. Cattani), with the logistic support of the Conseil d'Architecture, d' Urbanisme et de l' Environnement de la Somme (T. Rauwel)

and the Association Maisons Paysannes (N. Dupré, E. Petzny). This project is supported by LabEx ARCHIMEDE from "Investissement d'Avenir" program ANR-11-LABX-0032-01. We also gratefully acknowledge the help of G. Bay, B. Breart, G. Fercoq du Leslay, S. Gaudefroy, M.C. Geib Munier, E. Gontrand, C. Hénocque, T. Morcrette, G. Papin, M. Papin, the CAUE of Pas-de-Calais, and the Parc naturel régional des Caps et Marais d' Opale. All the pictures and drawings have been done by the author, except for Fig. 22.2b (Parc naturel régional des Caps et Marais d'Opale).

${ }^{2}$ The heights of these bases are variable, from two or three superposed bricks to half a meter. Bases are made from flint pebbles in the older buildings.

${ }^{3}$ Ethnographic literature mentions that binding can be done with rye stalk in ancient buildings (Devismes 1958 , p. 16).

${ }^{4}$ There are semi-hidden frameworks as well (when the horizontal beams and just some main timber posts are visible from the exterior).

${ }^{5}$ Especially in Haute Normandie and partially in Oise, where visible frameworks are made with the available oak. In Picardie, where the quality of timber is poor due to the chalky bedrock, hidden frameworks are mainly chosen.
} 
then mixing it with new sediment, is also a current practice in the restoration of buildings.

In terms of installation, the most common technique used is the application of daub pressed against the frame, either manually (Fig. 22.2a ) or with specific tools (Dupré 1988 , p. 241). Daub can be installed from the exterior of the wall, as well as from the interior (in the latter case, the daub is smoothed afterwards to finish the outer surface).

When the horizontal laths or bars are more spaced, an elongated lump of daub is shaped and installed, overlapping these frame elements (" torchis à cheval ," Fig. $22.2 \mathrm{~b}$ ). In this case, daub lays on laths and on underlying layers of earthen material (Lahure 1989 , p. 15). The daub is piled vertically rather than thrown against the wattle (i.e., Les gestes du torchis 2007 ). However, the frame has a supporting role for the earthen material. When the frames have less space between them, there is a tendency to use shorter straws as vegetal temper (often chopped stalks) in order to allow the daub to easily penetrate between the laths.

By comparing wattle and daub to other load-bearing techniques using earthen materials (cob, pisé, mudbricks), it can be noted that wattle and daub allows the realization of the timber framework and the roof before the installation of the

\section{p. 278}

earthen material . This technique is then suitable for both temperate and rainy climates, such as in northern France. On the other hand, in some nearby regions with similar climates (i.e., Vandée), cob is the current technique employed in vernacular architecture (Milcent 2006). Environmental constraints are not the only relevant factor in the constitution of traditional architectural practices. Nowadays, wattle and daub is often considered to be an outdated and less resistant building technique, but it offers good technical performances and durability if regularly maintained.

\footnotetext{
Abandonment, Decay and Fire of Wattle and Daub Dwellings

Various decay and formation processes recorded on wattle and daub dwellings are discussed here; all of them result in specific deposits from an archaeological point of view. The first case concerns a barn in Les Alleux (Somme, Picardie). In 2011, some bricks were stolen from the base of the building, resulting in the instability of the timber framework. During the following winter, half of the building collapsed. The entire timber framework collapsed, dragging down the earthen material still on it. The result of this punctual decaying process is a vast planar deposit, with more or less equal thickness and an absence of included artifacts (Figs. 22.3 and 22.5a). The
} 
earthen material comes entirely from the collapsed wattle and daub, and the sedimentation occurred very quickly ${ }^{6}$.

p. 279

Most of the time, the wattle and daub decay processes begin with water seepage from damaged roofs, resulting in the slow erosion of earthen walls. The recurrence and the long duration of this process cause a thick sedimentation of earthen materials at the base of the wall, normally when buildings are completely abandoned or when there is a lack of maintenance during a secondary use of the space. The deposit is generally thicker at the base of the wall and becomes thinner in its distal part (Figs. 22.4 and 22.5c ). This shape results from the slow sedimentation and the redistribution of fine particles and earthen aggregates, due to gravity and superficial water flowing. The deposit could show inclusions of artifacts, when trampled and discarded refuse are part of the sedimentation. Effectively, abandoned or non- maintained spaces, full of architectural debris, "attract" refuse (Cf. Schiffer 1987, p. 62). During the formation of the deposit at the base of the wall, the timber framework is usually still standing and is less damaged from moisture and mechanical shocks.

Furthermore, it can be noticed at a dwelling in Rambures (Picardie) that the fi rst step of decay corresponds to a sudden and punctual falling of earthen material from the top of the wall. In this case, the seepage from the roof was considerable, and the resulting layer has a plano-convex profi le (Fig. 22.4 ). This fast sedimentation is normally followed by the slow erosion of earthen material still standing on the wall, as mentioned above. Various processes can contribute to wattle and daub decay, resulting in a "sum" of various characteristic layers. Effectively, it is impossible to look at these processes in a static way. During archaeological excavations it is always important to take into account the fact that post-depositional processes can modify the primary sedimentation, in particular occupation surface leveling, earth moving.

p. 280

bioturbation, weathering, and pedoturbation. The modality and the speed of burying are other relevant variables for the preservation of archaeological layers.

Maintenance processes (Fig. 22.5d ) can remove some of the wattle and daub debris coming from the walls, leaving just a very thin layer of sediments on the occupation surfaces around the building. Moreover, wattle and daub dwellings are sometimes completely dismantled in order to reuse timber and earthen materials or to discard debris elsewhere (Fig. 22.5e ).

One burnt dwelling has been observed in Marais Vernier (Normandie). Just a small percentage of daub was completely burnt, and the rest shows just light traces of

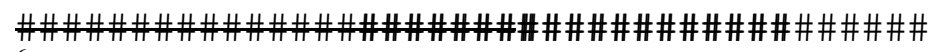

${ }^{6}$ The rest of the building was demolished in 2013, pushing the walls still standing. Both the collapse of the framework and its intentional destruction produce very similar deposits in terms of shape. Both involve a rapid deposition of sediments, resulting from the fall of the whole timber framework. 
burning or no traces at all, confirming experimental data (Bankoff and Winter 1979, p. 13; Cavulli and Gheorghiu 2008, p. 41; Fercoq du Leslay 1997, pp. 102-103).

\section{Conclusions}

Wattle and daub construction techniques are extremely variable. The ethnographic enquiry provides some explanatory models, which must not be considered to be fi xed in time and space. The raw materials and techniques used can demonstrate the adaptation to the ecological environment, which is a recurring characteristic of vernacular architecture. However, the geographical variability of techniques and settlement organization also depends on the socioeconomic context and the historical trajectory of local architectural habits. The aesthetic perception of architectural

\section{p. 281}

models has contributed to the formation of regional and social identities, which are variably marked. This cognitive process is largely involuntary, indefinite, and non-formalized. Local masons and carpenters, who specialize in the realization of timber frameworks, lath production and daub installation, have contributed to the transmission of micro-regional architectural models and savoir -faires . Nowadays this variability is slowly disappearing, due to the increasingly limited number of these specialized craftsmen.

This field enquiry focused on macroscopic observations of the shape and composition of layers related to wattle and daub decay ${ }^{7}$. This kind of approach can furnish useful data on abandonment dynamics and the role played by various formation processes, both cultural and non-cultural, thereby explaining the presence or lack of sedimentation at the base of the walls. At present, it seems that the series of macroscopic observations proposed here are not enough to clearly discern wattle and daub

\section{p. 282}

techniques from other earthen construction techniques in deposits related to decayed structures. Micromorphological studies on earthen construction technology are preferable for this purpose (Cammas 2003 ; Wattez 2009 ).

The setting of an ethnoarchaeological reference system about the interpretation of the built space, including the traces left by dwellings and their micro-biography, can provide relevant data on settlement organization, technological complexity and human behaviors.

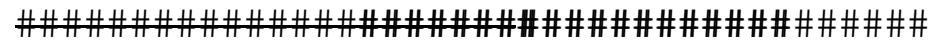

${ }^{7}$ Correct observations can be made by extensive excavation, coupled by frequent cross-sections of layers, in order to observe the shape of the layer and its relationship with the surrounding sedimentation.
} 


\section{References}

Bankoff, H. A., \& Winter, F. A. (1979). A house burning in Serbia. Journal of Field Archaeology, 32 , 8-14.

Cammas, C. (2003). L'architecture en terre crue à l'Âge du fer à l'époque romaine: Apports de la discrimination micromorphologique des modes de mise en oeuvre. In C.-A. de Chazelles \& A. Klein (Eds.), Échanges transdisciplinaires sur les constructions en terre crue (pp. 33-53). Montpellier: Éditions de l'Espérou (École nationale supérieure d'architecture de Montpellier).

Cavulli, F., \& Gheorghiu, D. (2008). Looking for a methodology burning wattle and daub housing structures. A preliminary report on an archaeological experiment. Journal of Experimental Pyrotechnologies, 1, 37-43.

Devismes, R. (1958). Les Méthodes traditionnelles de la construction rurale à Mons-Boubert. Amiens: CRDP.

Dupré, N. (1988). Culture technique et savoir-faire traditionnels du bâtiment: Département de la Somme . Paris: Maisons Paysannes de France.

Épaud, F. (2009). Approche ethnoarchéologique des charpentes à poteaux plantés: Les loges d'Anjou-Tourraine. Archéologie Médiévale, 39, 121-160.

Fercoq du Leslay, G. (1997). Terre crue, terre cuite. In J.-L. Brunaux \& P. Meniel (Eds.), La résidence aristocratique de Montmartin (Oise) du IIIe au IIe s. av. J.-C. (DAF, 64) (pp. 99-105). Paris: Maison des Sciences de l'Homme.

Houben, H., \& Guillaud, H. (1989). Traité de construction en terre . Marseille: Éditions Parenthèses. 3rd edn., 2006 .

Lahure, F. (1989). Fascicule technique sur la mise en oeuvre du torchis: À l'usage des professionnels . NotreDame-de-Bliquetuit: Parc naturel régional de Brotonne.

Les gestes du torchis (2007). Documentary. Directed by Samuel Coquelle. Arras: CAUE du Pasde-Calais, Parc naturel régional des Caps et Marais d'Opale.

Milcent, D. (2006). La bourrine: Architecture rurale en bauge et couverture végétale dans le Nord-Ouest de la Vendée. In Situ, 7 , 2-13.

Schiffer, M. B. (1987). Formation Processes of the Archaeological Record. Albuquerque: University of Chicago Press.

Schiffer, M. B. (1995). Behavioral Archaeology: First principles . Salt Lake City, UT: University of Utah Press.

Wattez, J. (2009). Enregistrement sédimentaire de l'usage de la terre crue dans les établissements néolithiques du sud de la France: Le cas des sites du Néolithique Final de La Capoulière 2 et du Mas de Vignoles IV. In A. Beeching \& I. Sénépart (Eds.), De la maison au village. L'habitat néolithique dans le Sud de la France et de Nord-Ouest méditerranéen (pp. 199-218). Paris: Société Préhistorique Française. 


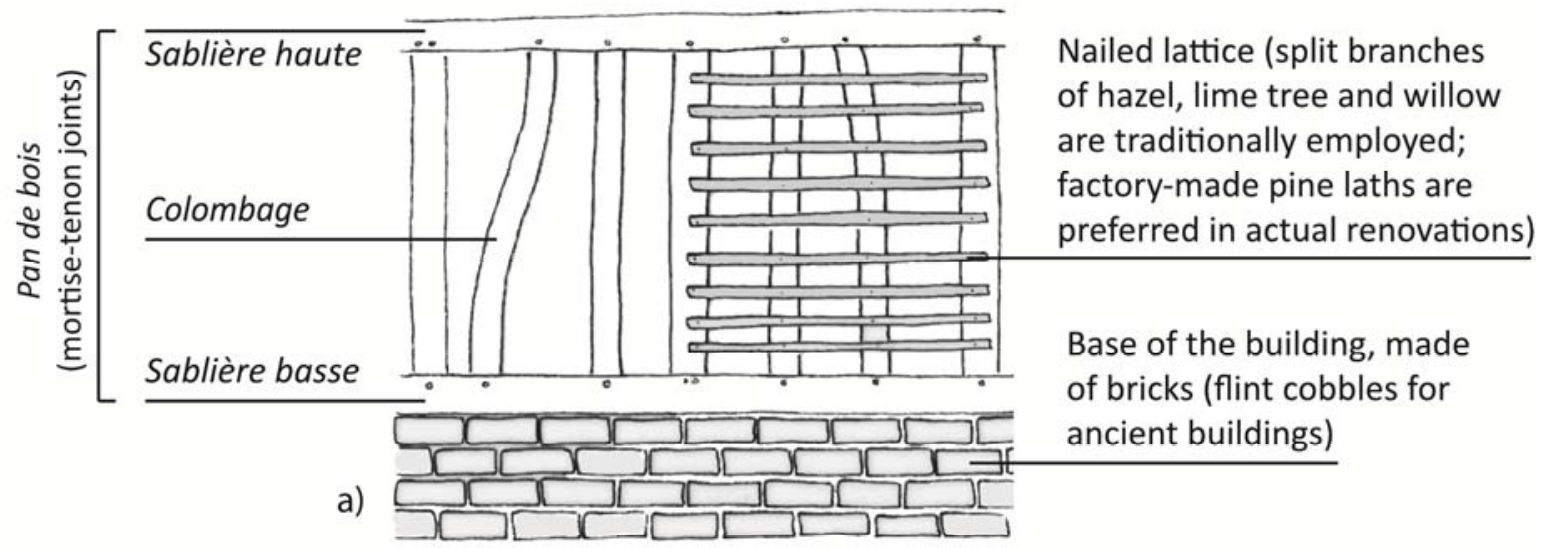

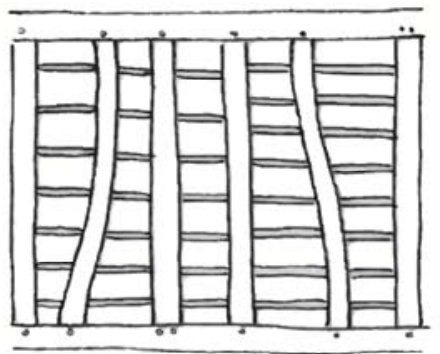

b)

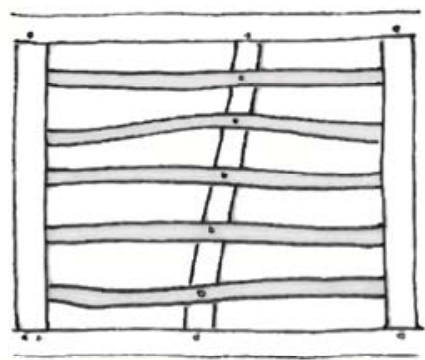

c)

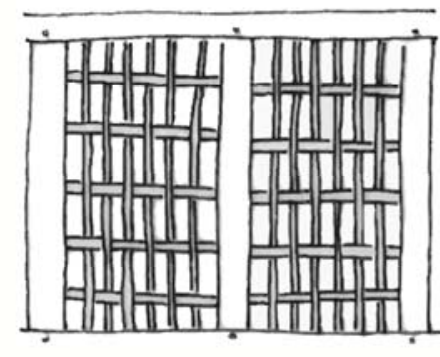

d)

Fig. 22.1 Examples of variability in timber frameworks from Northern France: ( a ) few spaced to moderately spaced laths, recorded in the Departments of Somme, Oise, and Pas-de-Calais; ( b ) barreaudage (horizontal bars) fi xed by notches on the timber framework, recorded in Haute Normandie and in western Oise; ( c ) gaulettes (thick and spaced bars), recorded in Normandie (Marais Vernier); ( d ) Flemish vertical wattle, that can be horizontal in some areas of Pas-de-Calais.

$\#$
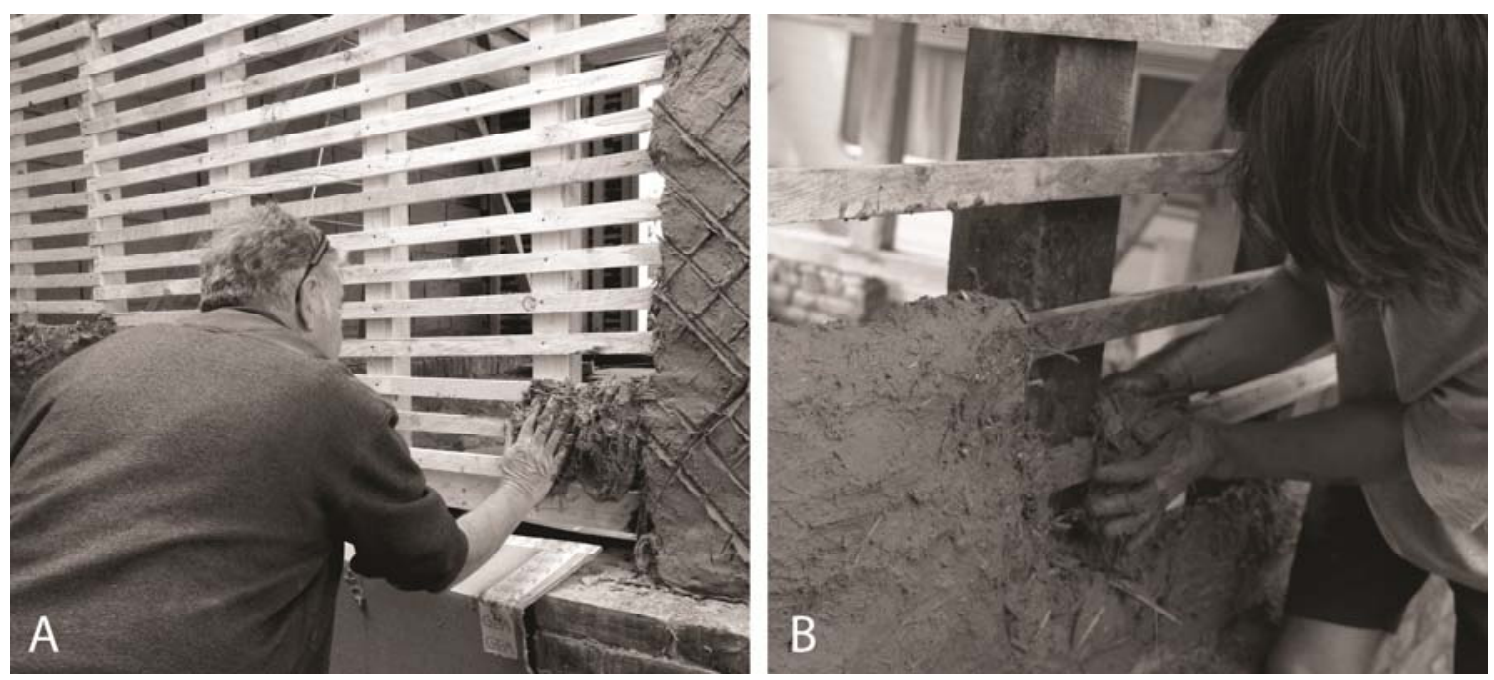

Fig. 22.2 Various techniques of daub installation: (a ) daub pressed against a closely spaced frame (with horizontal movements); ( b ) Elongated lump of daub set down on laths ("torchis à cheval"). Daub overlaps the horizontal element of the frame (picture: Parc naturel régional des Caps et Marais d'Opale). 


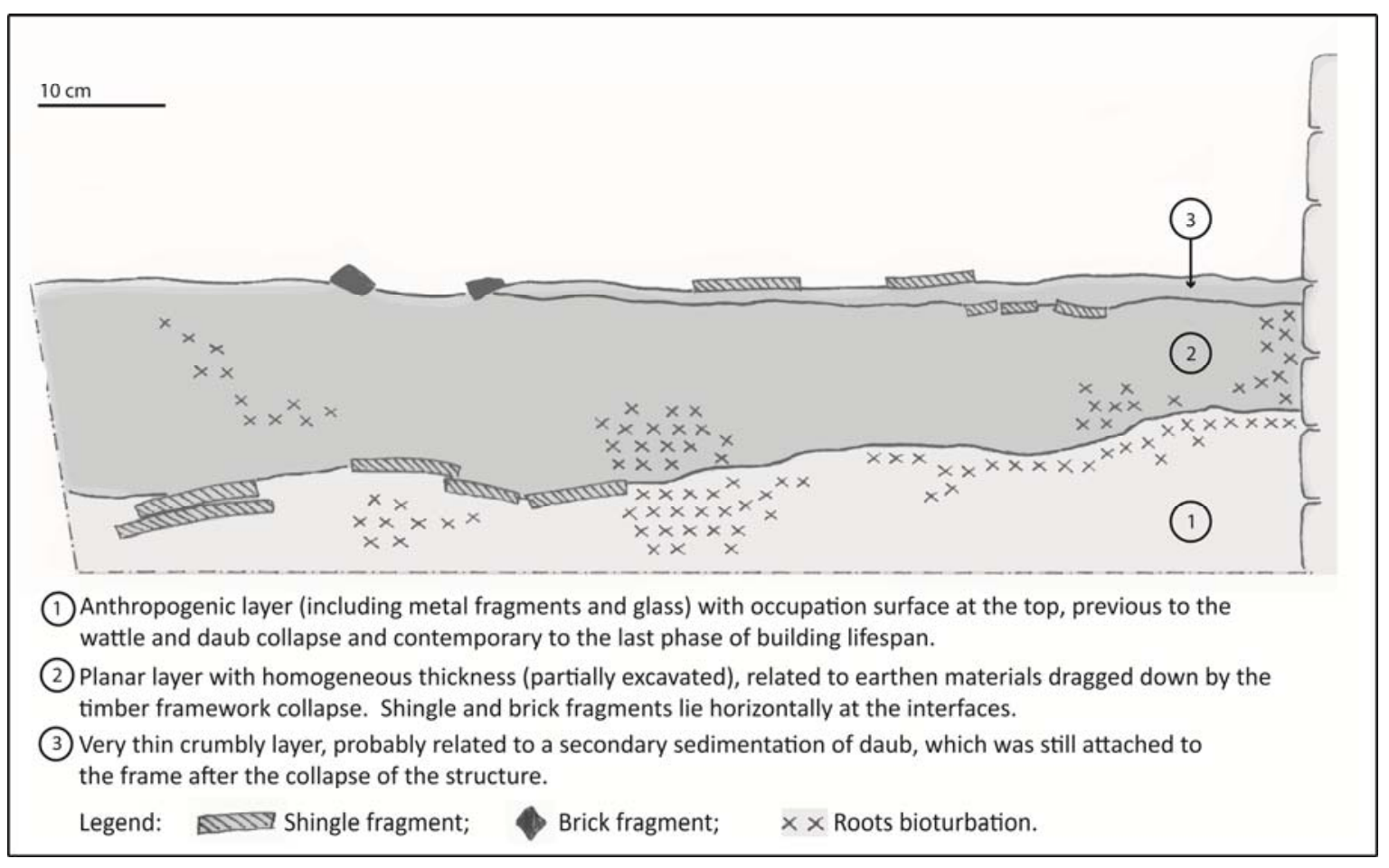

Fig. 22.3 Partial cross section of a planar layer resulting from the collapse of a wattle and daub barn (Cf. Fig. 22.5a ) in Bainast-Les Alleux (Somme).

\#

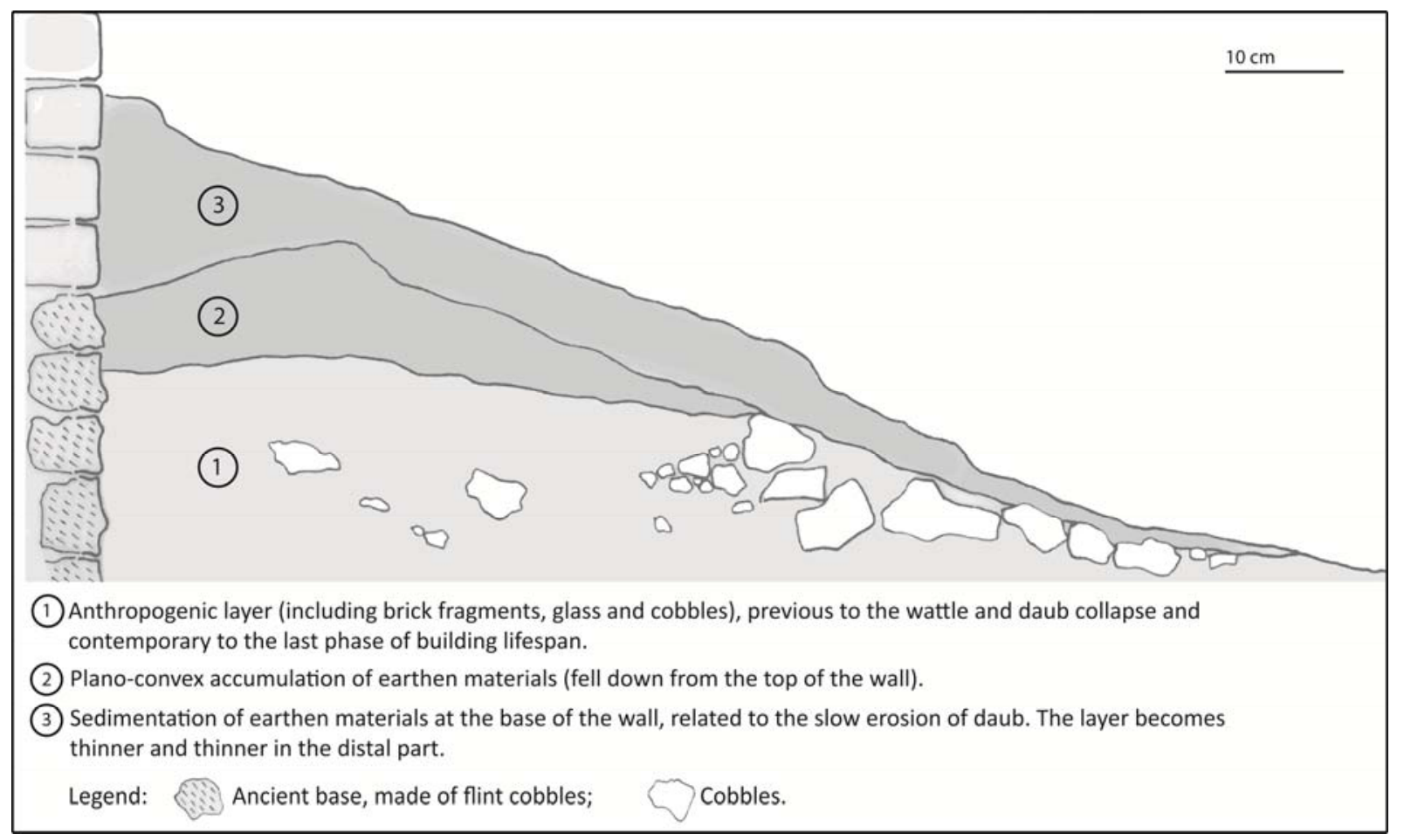

Fig. 22.4 Cross section of a layer resulting from the sedimentation of earthen materials at the base of a wall (Cf. Fig. 22.5b, c ) in Rambures (Somme) 


\begin{tabular}{|c|c|c|}
\hline \multicolumn{2}{|r|}{ Formation processes and maintenance degree } & Macroscopic record \\
\hline \multirow{4}{*}{ 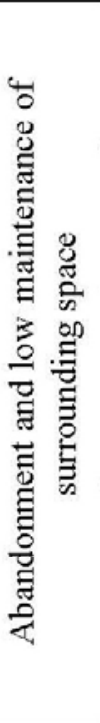 } & $\begin{array}{l}\text { 1-Fast collapse of the entire wall, engendered by } \\
\text { static problems at the base of the load-bearing } \\
\text { timber framework }\end{array}$ & \multirow{2}{*}{$\begin{array}{l}\text { A) Planar layer, with more or less } \\
\text { regular thickness in cross-section, } \\
\text { without artifact inclusion. If leveling } \\
\text { occurs after the intentional demolition, } \\
\text { the possibility of artifacts inclusion } \\
\text { increases. }\end{array}$} \\
\hline & $\begin{array}{l}\text { 2- Intentional demolition, pushing down the } \\
\text { walls, without relocation of architectural debris. } \\
\text { Surface leveling sometimes follows this process. }\end{array}$ & \\
\hline & $\begin{array}{l}\text { 3- Fast collapse of earthen materials (and part of } \\
\text { the frame) from the top of the wall, engendered } \\
\text { by considerable water seepage from the } \\
\text { damaged roof. }\end{array}$ & $\begin{array}{l}\text { B) Earthen (and timber) debris } \\
\text { accumulation at the base of the wall, } \\
\text { normally with a plano-convex profile, } \\
\text { without artifact inclusions. }\end{array}$ \\
\hline & $\begin{array}{l}\text { 4-Slow sedimentation of eroded earthen } \\
\text { materials from the wall (both interior and } \\
\text { exterior), especially engendered by water } \\
\text { seepage from the roof. }\end{array}$ & $\begin{array}{l}\text { C) Massive accumulation of earthen } \\
\text { materials, thicker at the base of the wall } \\
\text { and thinner on the opposite side (cross- } \\
\text { section observation). Possible inclusion } \\
\text { of discarded and relocated artifacts. }\end{array}$ \\
\hline \multirow{2}{*}{ 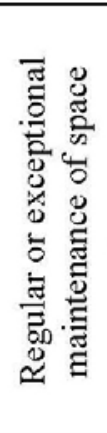 } & $\begin{array}{l}\text { 5-Further to process } 1,3 \text { or } 4 \text {, the architectural } \\
\text { debris are relocated (regular or ad hoc clean-up, } \\
\text { Cf. Schiffer } 1987, \text { pp. } 64-65 \text { ). }\end{array}$ & $\begin{array}{l}\text { D) Construction debris can be found } \\
\text { elsewhere. At the place of the primary } \\
\text { sedimentation a very thin layer of } \\
\text { residual earthen materials is usually } \\
\text { observed. }\end{array}$ \\
\hline & $\begin{array}{l}\text { 6- Intentional demolition with concurrent } \\
\text { relocation of architectural debris, often with } \\
\text { reuse of timber and earthen material. }\end{array}$ & $\begin{array}{l}\text { E) It's possible to recognize the } \\
\text { emplacement of the building, but the } \\
\text { identification of the wattle and daub } \\
\text { presence is more difficult. }\end{array}$ \\
\hline
\end{tabular}

Fig. 22.5 Summary of formation processes and macroscopic results mainly observed during the ethnoarchaeological enquiry in northern France. 